\title{
THE ROLE OF TECHNOLOGY IN ENHANCING ENGAGEMENT AND BUILDING COMMUNITIES OF PRACTICE WITHIN TOURISM EDUCATION
}

\author{
F. Taylor, R. Welton, D. Ellicott \\ Nottingham Trent University (UNITED KINGDOM) \\ faye.taylor@ntu.ac.uk,rachel.welton@ntu.ac.uk,david.ellicott@ntu.ac.uk
}

\begin{abstract}
Education research consistently establishes a strong correlation between active learning and subject engagement (Roehl, Reddy and Shannon, 2012; Prince, 2004). The argument put forward is that, those learners who are actively engaged in their learning, will form stronger connections to the subject matter, become more engaged (Stone, 2016), have better recall of material and are more inclined to reflect favourably upon the learning experience (Jensen, Kummer and Godoy, 2015).

The use of technology, flipped and blended approaches are widely cited as a means to induce active learning (Rahman et al, 2015). Using a case study of a final year, undergraduate Tourism module at Nottingham Business School, which is delivered across multiple business study programmes, this research will consider the impact of a variety of technologically aided interventions, such as, engagement with Padlet, Video Blogs and Poll everywhere, Twitter, etc. designed to stimulate "active" learning and make students feel part of a learning community.

The learning from this module has been seen as good practice within Nottingham Trent University. It has promoted higher levels of engagement with lectures and increased participation in interactive learning, to form strong connections with the subject matter. Introducing greater interactivity through a variety of means within this module has not been without challenge, however benefits for both students and module tutors have been significant.
\end{abstract}

Keywords: Active learning, engagement, technology, learning community

\section{INTRODUCTION}

The International Tourism: Development, Impact and Sustainability module, is a broad based, final year undergraduate module delivered to students undertaking a range of Business degrees. The module is core for the BA (hons) International Business and optional for several other joint honours degrees. The module assumes no previous Tourism study, although some students may have studied Tourism in some capacity prior to their degree, and also benefit (on an increasing basis) from being able to draw upon a wealth of personal travel experience. The title of the module is largely indicative of the module content; we assess the development, growth and impact of the Tourism industry and consider strategies for future sustainability. The module also presents some of the contemporary challenges that the industry faces, such as Tourism and crisis, and the effects of climate change. The module's content is influenced by the research interests of the teaching team.

It is the only Tourism provision within the Business School, and, although the academic rigour is commensurate with the level it represents, similarly it must cater for the likelihood of no prior academic knowledge of Tourism. In essence, therefore, the module has become a form of 'catch all' which seeks to not only provide a foundational level of understanding but advanced, critical understanding too. The module faces certain challenges in that, some students fail to recognise the connectedness of Tourism to International Business and question its worth as part of their curriculum. Therefore, engaging and inspiring students to connect with the subject matter becomes an opportunity. 
There are several other challenges to be faced in the delivery of the module. Firstly, that this is the sole Tourism curriculum that the students will encounter throughout their entire degree, whilst being a final year module. Therefore, there is no prior preparation and grounding for the module. This means that the time available for delivery of the module is far less than required to offer appropriate coverage of key material within scheduled teaching time. Another major challenge, is that, on account of the module being rather distinct from their other modules, sometimes the it can be perceived as being less relevant or sometimes irrelevant to their core degree programme. It is also considered by some to be academically less challenging; an easy option. Therefore, a key consideration within the design of the module is to offer explicit links to their core programme, to provide resources to compliment the content of lectures and seminars (ensuring appropriate stretch and challenge) and to design teaching activities that are intellectually stimulating and engaging.

Aside from those conditions, there is growing disenchantment with a traditional lecture style mode of delivery (Meguid and Collins, 2017). Existing authors recognise a disconnect between traditional lecturing and engagement (Katyal et al, 2016). The value of using interactive methods to connect with students, which in turn impacts positively upon their attention, engagement, recall and enjoyment is widely noted (Yakovleva and Yakovlev, 2014). As Thomas (2012) asserts, interactive lectures, or "meaningful interaction between staff and students" encourage students to be actively involved in learning and promotes application of knowledge. There is growing exploration of how technological tools might facilitate interactive teaching, particularly with reference to large group lectures (Minasyan, 2016). Technology can aide learning as it can be used successfully to support visual, auditory and kinesthetic learning, therefore meeting the specific needs of learners (ibid, 2016). However, others caution that, "technology is only valuable if it addresses a specific instructional deficit and does not become a focus in its own right" (Caldwell, 2007 in Evans et al, 2015, p. 64).

This understanding, coupled with personal preference for interactive lecturing style, led the module leader to participate in a cross-University initiative named DELITE - Delivering Interactive Teaching in Education. This initiative is designed to promote and share best practice in terms of interactive teaching. The author's objective being to assess how technological tools could promote engagement with the subject matter, enjoyment and satisfaction within the Tourism module. Commencing in the 2015-16 academic year, a number of 'tools' were introduced into lectures and seminars. These included Poll everywhere, Padlet, Nearpod and Mentimeter. Poll everywhere, Nearpod and Mentimeter are audience response systems, which can be used to check knowledge and understanding. Padlet's utility is for pooling collaborative findings on a given task, facilitating notetaking and sharing ideas anonymously.

In addition to this, the module leader wanted to explore how other forms of technology in the form of social media might help create a more efficient and effective learning environment. This was spurred by the desire to stimulate interest and passion for the subject matter and also to expose students to a range of requisite knowledge that the teaching schedule wouldn't necessarily permit. Therefore, social networks were created under the banner of "Tourism Exchange" as bespoke for the module, seeking to create a community of enquiry surrounding the module. Via these networks, topical resources and debates concerning Tourism development, were shared. These were intended to complement the learning within lectures and seminars, but to also develop peripheral knowledge and stimulate a general interest in the subject matter.

The goal of the research therefore was ultimately to assess the impact that these technological interventions have upon student engagement, learning and satisfaction with learning experience. Another dimension to this is, of course, the impact upon course outcomes. However, it will be more challenging to isolate the impact of these interventions on outcomes when they are amongst a range of measures being implemented to improve outcomes e.g. change in assessment strategy. It is clearly of value to pursue this avenue of research, but will require longitudinal attention. 


\section{METHODOLOGY}

The research is interpretivist in nature, seeking to uncover the multiple realities of our students' learning experiences and placing emphasis on the richness of how they respond to their learning activity (Thanh and Thanh, 2015). As a study in the exploratory stages of its development, a variety of data sources were used to develop an initial picture of the role and impact technology played in developing an interactive teaching and learning environment. These sources include module evaluation questionnaires which are collected on an annual basis, course committee meetings, direct anecdotal feedback from students and bespoke online surveys.

Survey data, both quantitative and qualitative in form, is collected on an annual basis, measuring student response and satisfaction with the module. Over a three-year period from 2015-16 academic year to 2017-18, this totaled 233 responses. Questioning explored various dimensions of student satisfaction to include teaching, assessment and feedback, module organisation, relevance to business and overall satisfaction. The qualitative comments are of most interest within this paper as they offer detailed insight of the reasoning behind their satisfaction/ dissatisfaction associated with the dimensions noted above.

\section{RESULTS}

The module was recognised from a School perspective as the best performing module within the Business School Marketing cluster for the 2015-16 academic year on account of the module's student satisfaction survey outcomes. Additionally, the module leader was shortlisted in the 2014-15 academic year for a University Outstanding Teacher's Award. This award originates from student led nominations. These initial indicators of student voice are indicative of high levels of student satisfaction with the teaching on the module, but further interrogation was needed to ascertain the extent to which technological interventions, designed to stimulate interactivity within teaching and learning on the module, are effective.

Thematic analysis of module evaluation qualitative data indicates strong levels of satisfaction with interactive, particularly technological aspects of module delivery. Comments such as, my tutor has made the module very, very interesting. Before, I was not interested in Tourism nor Sustainability. With the fantastic teaching methods and interactivity, this has been wonderful" indicate that not only has the interactivity made classes interesting and enjoyable, it has stimulated interest in an area the student had not previously found interest in (Yakovleva and Yakolev, 2014). Variety was also a dominant theme within student satisfaction. Students placed value on varied teaching methods, helping them to explore the subject from a variety of perspectives using a variety of approaches, deepening their eventual understanding and connection with the subject matter, as found also by Meguid and Collins (2017). As one student put it, "the differentiation of methods used in lectures and seminars makes the module more interesting". It is undeniable that interactive teaching methods have positively influenced student enjoyment and engagement in the module. Feedback is also suggestive of a positive impact upon student understanding.

This is not to suggest that satisfaction and engagement is reliant upon interactive teaching methods alone, but it is certainly a factor which can enhance a student's learning experience. Other themes that arose just as strongly, if not stronger than variety and interactivity were the enthusiasm and passion of the teaching team, as indicated by this quotation, "I particularly value all the teaching staffs' enthusiasm for the module and how they have made it very engaging."

Conversely, there are some notable downsides associated with technology assisted interactivity, from both a student and staff perspective. Firstly, social media permits efficient sharing of information. However, from a student perspective, this flow of information can be too much at times, causing information overload. Additionally, despite best laid plans and robust pre-testing, sometimes technology can fail, and this, on occasions caused a disruptive effect during lectures. At times, to set up a tool such as Poll everywhere, and accommodate any technical glitches, took up valuable time within the lecture. A similar result could have been obtained far more efficiently using an alternative interactive method such as directed questioning.

A notable theme of resentment came through from some students via the module evaluation surveys, in respect of the additional time they had to invest in engaging with the module's social networks and 
video podcasts. Whilst academic staff viewed this as 'value added' there was polarisation in response from students regarding how this was received.

In synergy with the outcomes of the DELITE project, there were a number of key outcomes of this research:

1. Students who experienced interactive lectures and teaching felt more engaged and involved with their learning.

2. Interactive content needs to be skillfully balanced within a session, to maintain student engagement and energy levels. Poor technical competency can be a factor of dissatisfaction.

3. A range of interactive approaches can appeal to a wider number of students within a cohort and draw in students who may lack confidence to interact with staff and peers via other means.

4. Interaction can encourage a more personalised learning environment and facilitate helpful, supportive dialogue between students and their tutors.

5. Student satisfaction can be increased through the use of interaction but increases in student satisfaction are never solely the consequence of introducing or increasing interaction in teaching.

6. Technology can facilitate wider participation from students but the focus must always remain on the pedagogy for any technology or tools to be effective. 


\section{CONCLUSIONS}

Evidence from this case study module and the wider DELITE project indicates that interactive learning is a characteristic of teaching shown to appeal to students, leading to greater engagement and learning within teaching sessions across subject areas. Interactive teaching and lectures have been seen to encourage and enable student participation; motivate students to contribute; promote student retention and learning of content; promote a personalisation of the learning experience for students, with interactive content and delivery developing the student-lecturer relationship. Creating interactive lectures and teaching may be limited by the taught environment and facilitating interaction between students and lecturers in large groups can be particularly challenging. Initial findings however are skewed in favour of technology being a factor to promote enjoyment within lectures over any impact necessarily upon learning or outcomes. To determine a correlation here, further research must be undertaken. A number of lessons have been learned so far and they are:

- Use a variety of interactive methods for best effect

- Invest in appropriate training for teaching staff to ensure that they can skillfully execute the tool

- Technology has the ability to cater to a diversity of learning styles and make all learners feel included on account of their anonymity

- Interactivity through technology should not substitute / detract from core messages (style over substance)

- Whilst technology can promote interactivity and satisfaction through enjoyment, it is secondary to personal relationships and enthusiasm as a factor of satisfaction

\section{REFERENCES}

Bryson, C. (2016). Engagement through partnership: Students as partners in learning and teaching in higher education.

Galea, C. (Ed.). (2017). Teaching business sustainability: From theory to practice. Routledge.

Jensen, J. L., Kummer, T. A., \& Godoy, P. D. d M. (2015). Improvements from a flipped classroom may simply be the fruits of active learning. CBE-Life Sciences Education, 14(1), ar5.

Meguid, E. A., \& Collins, M. (2017). Students' perceptions of lecturing approaches: traditional versus interactive teaching. Advances in medical education and practice, 8, 229.

Minasyan, E. T. (2016). Applications of interactive technologies in Business learning environment. Актуальные проблемы гуманитарных и естественных наук, (1-5), 86-88.

Prince, M. (2004). Does active learning work? A review of the research. Journal of Engineering Education, 93(3), 223-231

Katyal, R., Singh, A., Joshi, H. S., Chandra, S., \& Singh, K. (2016). Enhancing student's learning by introducing various interactive teaching-learning methods in large group. International Journal of Biomedical and Advance Research, 7(8), 363-368. 
Rana, N. P., \& Dwivedi, Y. K. (2016). Using clickers in a large business class: Examining use behavior and satisfaction. Journal of Marketing Education, 38(1), 47-64.

A.A. Rahman, B. Aris, M.S. Rosli, H. Mohamed, Z. Abdullah, N.M. Zaid. Significance of preparedness in flipped classroom. Paper presented at the 3rd international conference on internet services technology and information engineering 2015 (ISTIE 2015), Kuta, Bali Indonesia (2015)

Roehl, A., Reddy, A. L., \& Shannon, G. J. (2013). The flipped classroom: An opportunity to engage millennial students through active learning strategies. Journal of Family \& Consumer Science, 105(2), 44-49.

Thanh, N. C., \& Thanh, T. T. (2015). The interconnection between interpretivist paradigm and qualitative methods in education. American Journal of Educational Science, 1(2), 24-27.

Thomas, L. (2012). Building student engagement and belonging in higher education at a time of change: a summary of findings and recommendations from the What works? Student Retention \& Success programme. Published by Higher Education Academy Available at: https://www.heacademy.ac.uk/sites/defaultffiles/what_works_summary_report_1.pdf

Wassermann, S. (2017). The art of interactive teaching: Listening, responding, questioning. Routledge.

Yakovleva, N. O., \& Yakovlev, E. V. (2014). Interactive teaching methods in contemporary higher education. Pacific Science Review, 16(2), 75-80. 